\title{
PENGARUH RASIO KEUANGAN TERHADAP PERUBAHAN LABA
}

\author{
Sindik Widati ${ }^{1}$, Rita Putri Yuliandri ${ }^{2}$ \\ Universitas Pelita Bangsa, Program Studi Akuntansi \\ sindik.widati@pelitabangsa.ac.id
}

\begin{abstract}
ABSTRAK
Penelitian ini bertujuan untuk menguji dan menganalisis pengaruh Current Ratio (CR),Debt to Asset Ratio (DAR), Total Assets Turnover (TATO), Net Pofit Margin (NPM) secara simultan aupun parsial terhadap perubahan laba pada perusahaan manufaktur yang terdaftar di Bursa Efek Indonesia periode 2015-2019. Metode analisis data yang digunakan dalam penelitian ini adalah menggunkan metode regresi linier berganda. Sampel yang digunakan dalam penelitian adalah perusahaan manufaktur yang terdaftar di Bursa Efek Indonesia periode 2015-2019, mepublikasikan laporan keuangan secara berkala, dan dalam laporan keuangannya melaporkan laba. Berdasarkan kriteria tersebut, sampel yang digunakan dalam penelitian ini adalah 6 perusahaan otomotif. Hasil dari penelitian ini menunjukkan bahwa variabel CR, DAR,dan NPM tidak berpengaruh terhadap perubahan laba. Sedangkan TATO berpengaruh terhadap perubahan laba.
\end{abstract}

Kata Kunci: Perubahan Laba, Total Asset Turnover, Net Profit Margin, Debt to Asset Ratio, Current Ratio

\begin{abstract}
This study aims to examine and analyze the influence of Current Ratio (CR), Debt to Asset Ratio (DAR), Total Assets Turnover (TATO), Net Pofit Margin (NPM) simultaneously partially to changes in earnings at manufacturing companies listed on the Stock Exchange Indonesia period 2015-2019. Data analysis method used in this research is using multiple linear regression method. The sample used in the research is a manufacturing company listed on the Indonesia Stock Exchange period 2015-2019, publish financial statements on a regular basis, and in its financial statements reported earnings. Based on these criteria, the sample used in this research is 6 automotive companies. The results of this study indicate that the variables CR, DAR, and NPM have no effect on changes in earnings. While TATO effect on changes in earnings.
\end{abstract}

Keywords :Profit Change, Total Asset Turnover, Current Ratio, Debt to Asset Ratio, Net Profi Margin

\section{PENDAHULUAN}

Tujuan utama didirikannya suatu perusahaan yaitu memperoleh laba jangka panjang kemudian mempertahankan kelangsungan hidup perusahaan, serta mempengaruhi kesejahteraan masyarakat sebagai tanggung jawab sosial. Ketiga tujuan tersebut saling berkaitan satu dan lainnya, perusahaan ingin memperoleh laba jangka dimaksudkan agar perusahaan dapat terus bertahan hidup tanpa batasan waktu.

Untuk mencapai tujuan tersebut perusahaan tentunya harus dapat meningkatkan produktivitas dalam menjalankan usahanya, Agustina dan Sivia (2012).Kinerja suatu perusahaan dapat dilihat dari laporan keuangan perusahaan yang diterbitkan oleh perusahaan. Laporan keuangan perusahaan akan memberikan informasi mengenai posisi keuangan, hasil usaha dan perubahan posisi keuangan lainnya. Hal ini sesuai dengan tujuan laporan keuangan menurut PSAK No.1 yang menyatakan tujuan laporan keuangan adalah menyediakan informasi yang menyangkut posisi keuangan, kinerja serta perubahan posisi keuangan suatu perusahaan yang bermanfaat bagi sejumlah besar pemakai dalam pengambilan keputusan ekonomi.Agar laporan keuangan menjadi lebih berarti sehingga dapat dipahami dan dimengerti oleh berbagai pihak, perlu dilakukan analisis laporan keuangan.

Analisis laporan keuangan perlu dilakukan secara cermat dengan menggunakan metode dan teknik analisis yang tepat sehingga hasil yang diharapkan benar-benar tepat.Teknik analisis yang biasa digunakan adalah analisis rasio keuangan. Analisis rasio keuangan adalah membandingkan angkaangka yang ada dalam laporan keuangan untuk mengetahui posisi keuangan suatu perusahaan serta menilai kinerja manajemen dalam suatu periode tertentu. 
Salah satu parameter kinerja tersebut adalah laba. Laba pada umumnya dipakai sebagai ukuran dari prestasi yang dicapai oleh suatu perusahaan sehingga laba dapat dijadikan sebagai dasar untuk pengambilan keputusan invetasi dan prediksi untuk meramalkan perubahan laba yang akan datang. Laba yang diperoleh perusahaan untuk tahun yang akan datang tidak di pastikan, maka perlu adanya prediksi perubahan laba. Perubahan laba merupakan kenaikan atau penurunan laba per tahun, perubahan laba yang tinggi mengindikasikan laba yang diperoleh perusahaan tinggi, sehingga tingkat pembagian deviden perusahaan tinggi pula.

Maka dari itu, perubahan laba akan mempengaruhi keputusan investasi para investor yang akan menanamkan modalnya ke dalam perusahaan. Hal ini dikarenakan investor mengharapkan dana yang diinvestasikan ke dalam perusahaan akan memperoleh tingkat pengembalian tinggi. Berdasarkan latar belakang diatas, maka penelitian ini dimaksudkan untuk melakukan pengujian lebih lanjut mengenai rasio keuangan. Terutama yang berkaitan dengan manfaatnya dalam mempengaruhi perubahan laba dimasa yang akan datang, oleh karena itu Tugas Akhir ini berjudul "Pengaruh Rasio Keuangan Terhadap Perubahan Laba" (Studi Kasus Perusahaan Otomotif yang Terdaftar di Bursa Efek Indonesia Tahun 2015-2019).

\section{KAJIAN PUSTAKA}

\section{Laporan Keuangan}

Menurut (Munawir 2002:2 dalam Fitiriant 2016), Laporan Keuangan adalah hasil dari proses akuntansi yang dapat digunakan sebagai alat untuk berkomunikasi antara data keuangan atau aktivitas suatu perusahaan dengan pihak-pihak yang berkepentingan dengan dana atau aktivitas perusahaan tersebut. Menurut IAI (2012:5) mengemukakan pengertian laporan keuangan adalah struktur yang menyajikan posisi keuangan dan kinerja keuangan dalam sebuah entitas.Tujuan umum dari laporan keuangan ini untuk kepentingan umum adalah penyajian informasi mengenai posisi keuangan (Financial Performance), dan arus kas (cash flow) dari entitas yang sangat berguna untuk membuat keputusan ekonomis bagi para penggunanya.Untuk dapat mencapai tujuan ini, laporan keungan menyediakan informasi mengenai elemen dari entitas yang terdiri dari aset, kewajiban, networth, beban, dan pendapatan (termasuk gain dan loss), perubahan ekuitas dan arus kas. Informasi tersebut diikuti degan catatan, akan membantu pengguna memprediksi arus kas masa depan.

\section{Rasio Keuangan}

Rasio Keuangan adalah alat ukur yang paling sering digunakan dalam menganalisis laporan keuangan.Rasio keuangan menghubungkan berbagai perkiraan yang terdapat pada laporan keuangan sehingga kondisi keuangan dan hasil operasi suatu perusahaan dapat diinterpretasikan. Analisis keuangan yang mencakup analisi rasio keuangan, analisis kelemahan dan kekuatan financial akan sangat membantu dalam menilai prestasi manajemen masa lalu dan prospeknya di masa datang.

Rasio dapat memberikan indikasi apakah perusahaan masih memiliki kas yang cukup untuk memenuhi kewajiban finansialnya, besarnya piutang yang cukup rasional, efensiensi manajemen, persediaan, perencanaan pengeluaran investasi yang baik dan struktur modal yang sehat sehingga tujuan memaksimumkan kemakmuran pemegang saham dapat dicapai Andreas.

Menurut Kementrian Koperasi Usaha Kecil dan Menengah Republik Indonesia (2010) Analisis Rasio adalah analisis yang membandingkan antara satu rekening dengan rekening lainnya. Analisis Rasio sebagai bentuk untuk menilai posisi keuangan dalam perusahaan, sehingga dengan menggunakan analisis rasio, maka pengurus perusahaan dapat mengetahui posisi keuangan dari tahun ke tahun.

Menurut Irawati (2005:22) Rasio Keuangan merupakan teknik analisis dalam bidang manajemen keuangan yang dimanfaatkan sebagai alat ukur kondisi keuangan suatu perusahaan dalam periode tertentu, ataupun hasil-hasil usaha dari suatu perusahaan pada satu periode tertentu dengan jalan membandingkan dua buah variabel yang diambil dari laporan keuangan perusahaan, baik daftar neraca maupun laba rugi. Berikut ini adalah macam-macam Rasio Keuangan:

1. Rasio Likuiditas

Dermawan Sjahrial (2013:37) menyatakan bahwa Rasio Likuiditas menggambarkan kemampuan perusahaan membayar kewajiban jangka pendek (utang lancar) pada saat jatuh tempo dengan 
menggunakan aktiva lancar. Berdasarkan pendapat diatas maka likuiditas adalah rasio untuk mengukur kemampuan perusahaan untuk memenuhi kewajiban jangka pendek kepada kreditur yang harus segera dipenuhi.

Rasio Likiuditas yang digunakan dalam penelitian ini adalah Aktiva Lancar (Current Ratio). Current Ratio merupakan rasio yang digunakan untuk mengukur sampai sejauh mana tagihan-tagihan jangka pendek dari para kreditor dapat dipenuhi dengan aktiva yang diharapkan akan di konversi menjadi uang tunai dalam waktu dekat, Margaretha (2005) dalam Siti Fatimah (2014). Rumus yang digunakan untuk menghitung rasio ini adalah:

$$
\text { Current Ratio }=\frac{\text { Aktiva Lancar }}{\text { Utang Lancar }} \times 100 \%
$$

\section{Rasio Solvabilitas}

Rasio Solvabilitas digunakan untuk menjelaskan penggunaan utang untuk membiayai sebagian dari pada aktiva perusahaan.Pembiayaaan oleh hutang mempunyai pengaruh terhadap perusahaan karena utang mempunyai beban yang bersifat tetap.Kegagalan perusahaan dalam membayar bunga atas utang dapat menyebabkan kesulitan keuangan yang berakhir dengan kebangkrutan perusahaan.Tetapi penggunaan utang juga memberikan subsidi pajak atas bunga yang dapat menguntungkan pemegang saham.Karenanya penggunaan utang harus diseimbangkan antara keuntungan dan kerugiannya, (Muslich 2010).

Rasio Solvabilitas yang digunakan dalam penelitian ini adalah Rasio Hutang terhadap Total Akitva (Debt to Asset Ratio)Debt to Asset Ratiomerupakan perbandingan antar hutang lancar dan hutang jangka panjang dan jumalah seluruh aktiva diketahui.Rasio ini menunjuka beberapa bagian dari aktiva yang dibelanjai oleh hutang. Rumus yang digunakan untuk menghitung rasio ini adalah:

$$
\text { Debt to Asset Ratio }=\frac{\text { Total Utang }}{\text { Total Aktiva }} \times 100 \%
$$

\section{Rasio Aktivitas}

Rasio Aktivitas digunakan untuk mengukur seberapa efesien perusahaan menggunakan aktivanya.Rasio ini semuanya mempergunakan perbandingan antara tingkat penjualan dengan investasi dalam beberapa aktiva, (Muslich 2010). Aktiva yang rendah pada tingkat penjualan tertentu akan mengakibatkan semakin besarnya dana kelebihan yang tertanam pada aktiva tersebut. Dana kelebihan tersebut akanlebih baik bila ditanamkan pada aktiva lain yang lebih produktif.

Rasio aktivitas yang digunakan dalam penelitian ini adalah Rasio Perputaran Total Aktiva (Total Assets Turnover).Total Assets Turnover merupakan rasio yang digunakan untuk mengukur kemampuan dana yang tertanam dari keseluruhan aktiva yang berputar pada suatu periode atau kemampuan modal yang di investasikan untuk menghasilkan "revenue"(Arifin 2007). Rasio ini sangat berguna untuk menghitung nilai penjualan yang dihasilkan perusahaan dari setiap rupiah asetnya. Perusahaan yang memiliki margin keuntungan rendah biasanya memiliki Rasio Asset Turn Over tinggi, sementara yang margin keuntungannya tinggi memiliki Asset Turnover rendah. Rumus yang digunakan untuk menghitung rasio ini adalah:

$$
\text { Total As sets Turnover }=\frac{\text { Penjualan Bersih }}{\text { Total Aktiva }}
$$

\section{Rasio Profitabilitas}

Rasio Profitabilitas digunakan untuk mengukur kemampuan perusahaan dalam menghasilkan keuntungan pada suatu periode tertentu, (kasmir 2008). Rasio profitabilitas tergantung dari informasi akuntansi yang diambil dari laporan keuangan.Karenanyaprofitabilitas dalam konteks analisis rasio mengukur pendapatan menurut laporan rugi labadengan nilai buku investasi, kemudian dapat dibandingkan dengan rasio yang sama perusahaan pada tahun lalu.

Rasio Profitabilitas yang digunakan dalam penelitian ini Rasio Laba Bersih (Net Profit Margin).Net Profit Margin Merupakan rasio yang digunakan untuk mengukur kemampuan perusahaan dalam menghasilkan keuntungan bersih setelah dipotong pajak. Rumus untuk menghitung rasio ini adalah: 


\section{Perubahan Laba}

\section{Net Profit Maroin $\frac{\text { Laba Bersih Setelah Paiak }}{\text { Peniualan Bersih }}$ X 100\%}

Setiap perusahaan berusaha untuk memperoleh laba yang maksimal. Laba yang diperoleh perusahaan akan berpengaruh terhadap kelangsungan hdup perusahaan tersebut. Perusahaan pasti menginginkan adanya peningkatan laba yang diperoleh setiap tahunnya.Peningkatan dan penurunan laba dapat dilihat dari perubahan laba.Perubahan laba adalah peningkatan dan penurunan laba yang diperoleh perusahaan dibandingkan dengan tahun sebelumnya. Rumus untuk menghitung perubahan laba adalah :

$$
\Delta \mathrm{Y} \text { it }=\frac{(\mathrm{Yit}-\mathrm{Yit}-1)}{\mathrm{Yit}-1}
$$

\section{HIPOTESIS}

Berdasarkan latar belakang yang telah diuraikan, serta rumusan masalah dan tujuan penelitian yang telah di uraikan dalam pendahuluan, maka berikut adalah hipotesis yang dapat di ambil dalam penelitian ini :

\section{Pengaruh Current Ratio(CR) terhadap Perubahan Laba}

Current Ratio menunjukan perbandingan antara aktiva lancar dengan utang lancar suatu perusahaan.Current Ratio yang tinggi menunjukkan adanya kelebihan aktiva lancar yang dapat menutupi utang lancar suatu perusahaan. Hal ini dikarenakan Current Ratio yang tinggi menunjukan adanya kelebihan aktiva lancar yang tidak baik terhadap profitabilitas perusahaan karena aktiva lancar menghasilkanreturn yang lebih rendah dibandingkan aktiva tetap.

\section{$\mathbf{H}_{1}$ : Current Ratio berpengaruh positif terhadap perubahaan laba.}

\section{Pengaruh Debt to Assets Ratio terhadap Perubahan Laba}

Debt to Assets Ratio menunjukan perbandingan antara total kewajiban dengan total aktiva. Semakin tinggi Debt to Assets Ratio maka perubahan laba yang diperoleh perusahaan semakin rendah.Hal ini dikarenakan Debt to Assets Ratio yang tinggi menujukkan proporsi kewajiban perusahaan lebih besar dari pada aktiva yang dimiliki perusahaan.Sehingga risiko yang ditanggung perusahaan semakin besar karena adanya kewajiban perusahaan untuk membayar beban bunga yang berdampak pada berkurangnya laba.

\section{$\mathrm{H}_{2:}$ Debt to Asset Ratio berpengaruh negatif terhadap perubahaan laba.}

\section{Pengaruh Total Assets Turnover terhadap Perubahan Laba}

Total Assets Turn Over merupakan rasio yang menunjukkan efektivitas penggunaan seluruh aktiva perusahaan dalam rangka menghasilkan pendapatan. Semakin tinggi total assets turn over maka perubahan laba yang diperoleh perusahaan semakin tinggi. Hal ini dikarenakan total assets turnover yang tinggi menunjukkan perusahaan dapat memanfaatkan aktiva yang dimiliki untuk meningkatkan penjualan yang berdampak pada meningkatnya laba.

\section{$\mathrm{H}_{3:}$ Total Asset Tornover berpengaruh positif terhadap perubahaan laba.}

\section{Pengaruh Net Profit Margin Terhadap Perubahan Laba}

Net profit margin merupakan rasio yang digunakan untuk mengukur kemampuan perusahaan memperoleh laba setelah pajak dari setiap rupiah penjualan.Semakin tinggi net profit margin maka perubahan laba yang diperoleh perusahaan semakin tinggi.Hal ini dikarenakan net profit margin yang tinggi menunjukkan kemampuan perusahaan dalam mendapatkan laba cukup tinggi.Perusahaan yang sehat seharusnya memiliki net profit margin yang positif yang menandakan bahwa perusahaan tersebut tidak mengalami rugi.

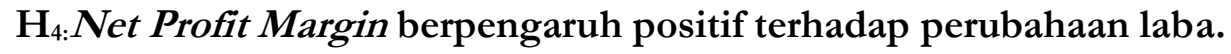




\section{Gambar 1}

\section{Kerangka Pemikiran}

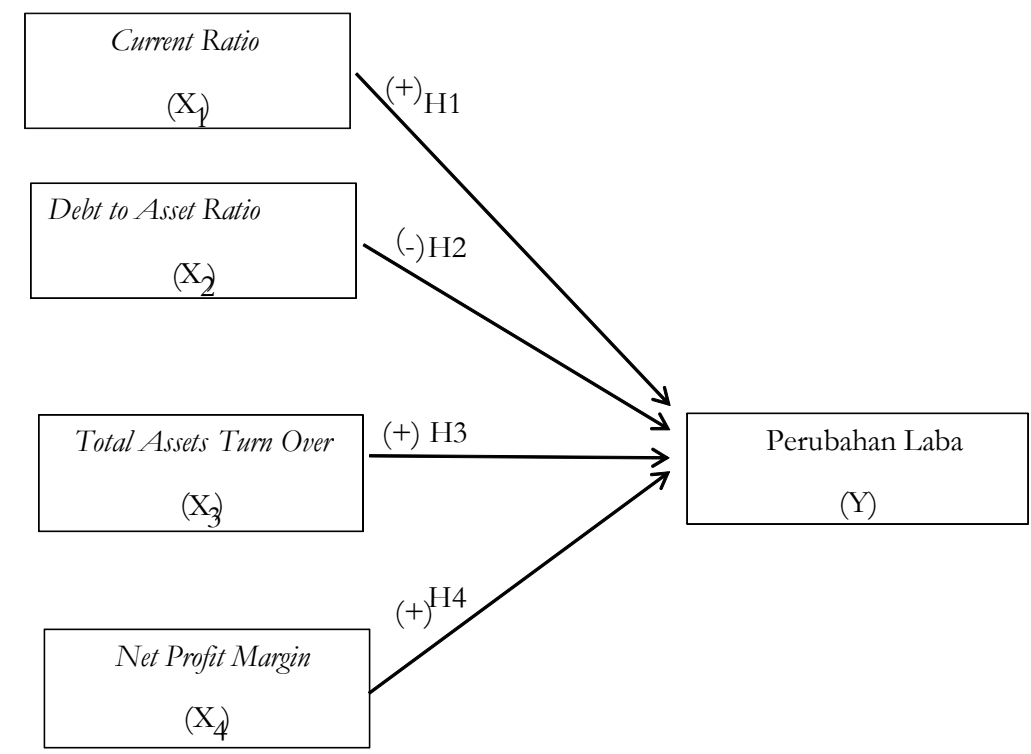

Sumber :Wisowo dan Pujiati (2011), Luluk Mubimatul Ifda dan Tiara Puspitasari (2016).

\section{METODE PENELITIAN}

Penelitian ini merupakan jenis penelitian kausal komparatif.Penelitian kausal komparatif adalah penelitian yang memiliki tujuan untuk menyelidiki adanya kemungkinan hubungan sebab akibat berdasarkan pengamatan terhadap fenomena yang diteliti.Data yang terdapat pada penelitian ini berbentuk angka sehingga termasuk penelitian kuantitatif.Penelitian ini menggunakan data sekunder berupa laporan keuangan pada perusahaan otomotif yang terdaftar di Bursa Efek Indonesia tahun 2015-2019.Populasi adalah wilayah generasi yang terdiri atas objek atau subjek yang mempunyai kualitas atau karakteristik tertentu yang ditetapkan oleh peneliti untuk dipelajari dan ditarik kesimpulannya (Sugiyono, 2007: 80). Menurut Supranto (2008: 22) populasi adalah sekumpulan dari seluruh elemen sejenis tetapi dapat dibedakan satu sama lain karena karakteristiknya. Populasi yang digunakan dalam penelitian ini adalah semua perusahaan otomotif yang terdaftar di Bursa Efek Indonesia periode 2015-2019 yang berjumlah 143 perusahaan.

Sampel adalah bagian dari jumlah dan karakteristik yang dimiliki oleh populasi (Sugiyono, 2007: 81).Penelitian ini hanya mengambil sebagian dari populasi, hal ini disebabkan keterbatasan penelitian.Adapun sampel penelitian ini diambil setelah memenuhi beberapa kriteria yang berlaku bagi penerapan definisi operasional variabel.Data yang digunakan dalam penelitian ini dikumpulkan dari laporan keuangan dan laporan tahunan perusahaan perusahaan otomotif yang terdaftar di Bursa Efek Indonesia selama tahun 2012 sampai tahun 2016.

Teknik sampling merupakan teknik pengambilan sampel atau sebagian elemen populasi untuk memahami karakteristik dari keseluruhan populasi.Menurut Cholid dan Abu (2005: 116), sampling purposive adalah teknik berdasarkan pada ciri-ciri atau sifat-sifat tertentu yang diperkirakan mempunyai sangkut paut erat dengan ciri-ciri atau sifat-sifat yang ada dalam populasi.Teknik pengambilan sampel yang digunakan dalam penelitian ini adalah metode purposive sampling, yaitu sampel yang ditarik dengan menggunakan pertimbangan. Teknik pengambilan sampel ini bertujuan untuk mendapatkan sampel yang representatif.

Kriteria pemilihan sampel dalam penelitian ini adalah :

a. Perusahaan yang tergolong dalam kelompok otomotif yang terdaftar di Bursa Efek Indonesia sampai tahun 2016.

b. Perusahaan otomotif yang mempublikasikan laporan keuangan secara berturut-turut untuk periode 2015-2019. 
c. Perusahaan otomotif yang dalam laporan keuanganya melaporkan Laba.

Berdasarkan kriteria pengambilan sampel, maka diperoleh 6 perusahaan Manufactur sector Otomotif yang terdaftar di Bursa Efek Indonesia sebagai sampel penelitian yang disajikan pada tabel 1 sebagai berikut:

Tabel 1

Definisi Operasional Variabel

\begin{tabular}{|c|c|c|c|}
\hline \multicolumn{4}{|l|}{$\begin{array}{l}\text { No } \\
\text { Dependen }\end{array}$} \\
\hline $\begin{array}{l}\text { 1. Perubahaan } \\
\text { Laba }\end{array}$ & $\begin{array}{l}\text { Rasio yang menunjukkan kemampuan } \\
\text { perusahaan meningkatkan laba bersih } \\
\text { dibanding tahun sebelumnya. } \\
\text { (Harahap,2008) }\end{array}$ & Rasio & $Y=\frac{Y_{t}-Y_{t-1}}{Y_{t-1}}$ \\
\hline \multicolumn{4}{|l|}{ Independen } \\
\hline 2. Current Ratio & $\begin{array}{l}\text { Rasio untuk mengukur kemampuan } \\
\text { perusahaan dalam membayar } \\
\text { kewajiban jangka pendek atau hutang } \\
\text { yang segera jatuh tempo pada saat } \\
\text { ditagih secara keseluruhan. (Kasmir, } \\
\text { 2014) }\end{array}$ & Rasio & $\frac{\underline{\text { Aktiva Lancar }}}{\text { Kewajiban Lancar }}$ \\
\hline Debt to Asset Ratio & $\begin{array}{l}\text { Rasio hutang yang digunakan untuk } \\
\text { mengukur perbandingan antara total } \\
\text { hutang dengan total aktiva. ( Kasmir, } \\
\text { 2014) }\end{array}$ & Rasio & $\frac{\text { Total Hutang }}{\text { Total Aktiva }}$ \\
\hline 4. Total Assets Turnover & $\begin{array}{l}\text { Permbagian antara penjualan dengan } \\
\text { total asetnya. Martono dan } \\
\text { Harjito (2008) }\end{array}$ & Rasio & $\frac{\text { Penjualan Bersih }}{\text { Total Aktiva }}$ \\
\hline 5. Net Profit Margin & $\begin{array}{l}\text { Net profit margin Merupakan rasio yang } \\
\text { digunakan untuk mengukur } \\
\text { kemampuan perusahaan dalam } \\
\text { menghasilkan keuntungan bersih } \\
\text { setelah dipotong pajak. Martono dan } \\
\text { Harjito (2008) }\end{array}$ & Rasio & $\frac{\text { Laba bersih }}{\text { Penjualan }}$ \\
\hline
\end{tabular}

Sumber: Data diolah penulis, 2020.

Metode yang digunakan untuk mengumpulkan data dalam penelitian ini adalah metode dokumenter yaitu pengumpulan data yang dilakukan dengan mempelajari catatan-catatan atau dokumen perusahaan (datasekunder) serta studi pustaka dari berbagai literatur dan sumber-sumber lainnya yang berhubungan dengan Perubahaan Laba. Data sekunder berisi tentang data-dataannual report yang mencakup data Rasio Keuangan yang meliputi Current Ratio, Debt to Asset Ratio, Total Asset Turnover, Net Profit Margin pada perusahaan Otomotif yang listing di BEI periode tahun 20152019.

\section{HASIL DAN PEMBAHASAN}

Manufactur yang terdaftar selama periode penelitian berjumlah 143 perusahaan Manufactur.Namun berdasarkan kriteria sampel yang ada, makadalam penelitian ini hanya digunakan sampel sebanyak 6 perusahaan. Periode penelitian yang digunakan adalah lima tahun yaitu tahun 2015-2019 sehingga terdapat 30 data yang diteliti.Sebanyak 6 perusahaan otomotif yang ditetapkan menjadi sampel dalam penelitian ini yang dapat dilihat di dalam Tabel 2 berikut ini. 
Tabel 2

Sampel Penelitian

\begin{tabular}{|c|c|l|}
\hline No & Kode & \multicolumn{1}{|c|}{ NamaPerusahaan } \\
\hline 1 & ASII & PT.Astra International \\
\hline 2 & AUTO & PT.Astra Autopart \\
\hline 3 & BRAM & PT.Indo Kordsa \\
\hline 4 & INDS & PT.Indospring \\
\hline 5 & PRAS & PT.Prima Alloy Steel Universal \\
\hline 6 & SMSM & PT.Selamat Sampurna \\
\hline
\end{tabular}

Sumber: www.idx.co.id, data diolah 2020.

\section{Hasil Statistik Deskriptif}

Setelah data diperoleh, selanjutnya akan ditinjau secara deskriptif mengenai kondisi masingmasing variabel penelitian. Statistik Deskriptif digunakan untuk memberikan gambaran atau deskriptif suatu data yang dilihat dari nilai rata-rata (mean), nilai minimum, nilai maksimum, dan standar deviasi. Berikut ini adalah hasil uji statistik deskriptif menggunakan SPSS 22:

Tabel 3

Hasil Analisis Statistik Deskriptif

\begin{tabular}{llrrrr}
\hline & N & Minimum & Maximum & Mean & Std. Deviation \\
\hline LABA_Y & 30 &,- 98 & 24,63 & 1,1523 & 4,86070 \\
CR_X1 & 30 &, 30 & 3,86 & 1,6967 &, 71967 \\
DAR_X2 & 30 &, 17 &, 57 &, 3730 &, 11167 \\
TATO_X3 & 30 &, 23 & 1,50 &, 8283 &, 31309 \\
NPM_X4 & 30 &, 01 &, 17 &, 0867 &, 04611 \\
Valid N (listwise) & 30 & & & & \\
\hline
\end{tabular}

Sumber: Data diolah, 2020.

Berdasarkan output data SPSS Descriptive Statistics dapat ditarik kesimpulan sebagai berikut:

1. Variabel Current Ratio $\left(\mathrm{X}_{1}\right)$ memiliki rata-rata sebesar 1,6967, nilai standar deviasi 0,71967, nilai minimum 0,30 dan nilai maximum 3,86.

2. Variabel Debt to Asset Ratio $\left(\mathrm{X}_{2}\right)$ memiliki rata-rata sebesar 0,3730, nilai standar deviasi 0,11167, nilai minimum 0,17 dan nilai maximum 0,57 .

3. Variabel Total Asset Turnover $\left(\mathrm{X}_{3}\right)$ memiliki rata-rata sebesar 0,8283, nilai standar deviasi 0,31309, nilai minimum 0,23 dan nilai maximum 1,50 .

4. Variabel Net Profit Margin $\left(\mathrm{X}_{4}\right)$ memiliki rata-rata sebesar 0,0867, nilai standar deviasi 0,04611, nilai minimum 0,01 dan nilai maximum 0,17 .

5. Variabel Perubahan Laba (Y) memiliki rata-rata sebesar 1,1523, nilai standar deviasi 4,86070, nilai minimum $-0,98$ dan nilai maximum 24,63.

\section{Analisis Uji Asumsi Klasik}

\section{Uji Normalitas}

Uji normalitas bertujuan untuk menguji apakah dalam model regresi, variabel pengganggu atau residual memiliki distribusi normal atau tidak. Model regresi yang baik adalah memiliki distribusi normal atau mendekati normal. Dalam penelitian ini uji normalitas diuji menggunakan grafik histogram, Kolmogorov Smirnov,dan juga dilihat dari penyebaran data (titik) pada normal P-Plot of Regression Standarized Residual. 
Table 4

Kolmogorov Smirnov

\begin{tabular}{llr}
\hline & & Unstandardized Residual \\
\hline $\mathbf{N}$ & & 30 \\
Normal Parameters ${ }^{\text {a,b }}$ & Mean &, 0000000 \\
& Std. Deviation & 1,34480703 \\
Most Extreme Differences & Absolute &, 083 \\
& Positive &, 083 \\
& Negative &,- 064 \\
Test Statistic & &, 083 \\
Asymp. Sig. (2-tailed) & &, $200^{\text {c,d }}$ \\
\hline
\end{tabular}

a. Test distribution is Normal.

b. Calculated from data.

c. Lilliefors Significance Correction.

$\mathrm{d}$. This is a lower bound of the true significance.

Sumber: Data diolah, 2020.

Berdasarkan table 4.3 diatas dapat diketahui bahwa nilai Kolmogorov-smirnov adalah 0,083 dengan tingkat signifikan pada 0,200, karena nilai Asymp. Sig. (2_tailed) lebih besar dari 0,05 maka dapat disimpulkan bahwa data residual berdistribusi normal. Untuk jelasnya, berikut turut dilampirkan grafik histogram dan plot data yang berdistribusi normal.

\section{Gambar 2 \\ Hasil Uji Normalitas}

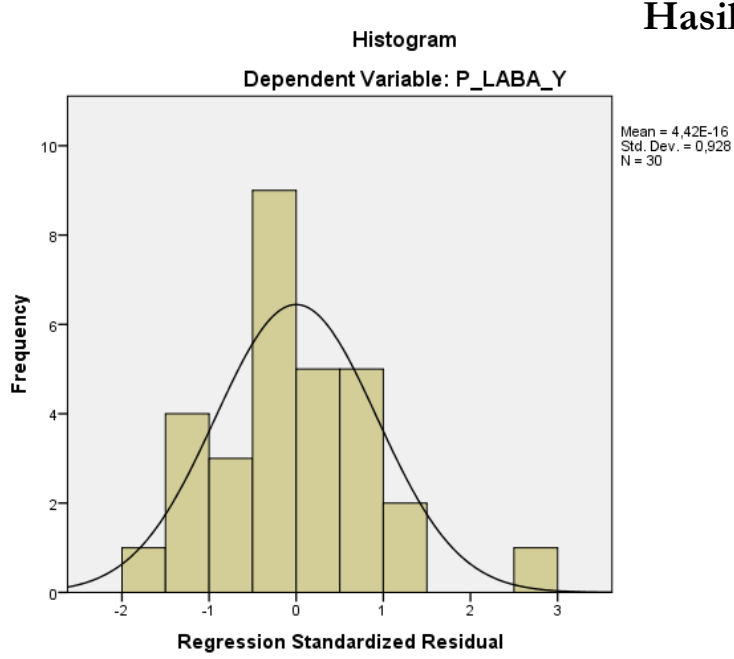

alitas

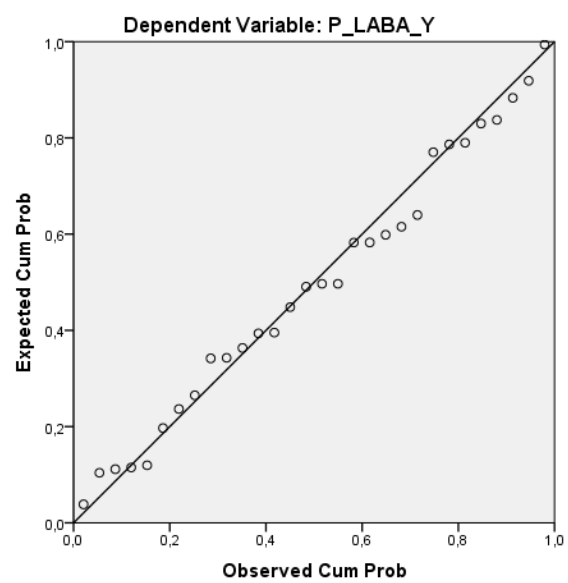

Sumber: Data diolah, 2020.

Berdasarkan gambar diatas, dapat dilihat bahwa grafik histogram tidak condong ke kiri dan ke kanan, sehingga dapat dikatakan data berdistribusi normal. Hal tersebut terlihat jelas gambar normal P-P Plot diatas, titik-titik menyebar disekitar garis diagonal dan penyebaranya mengikuti garis diagonal, sehingga dapat disimpulkan bahwa (data) residual terdistribusi normal.

\section{Uji Heterokedastisitas}

Uji heteroskedastisitas bertujuan menguji apakah dalam model regresi terjadi ketidaksamaan varian dari residual satu pengamatan ke pengamatan yang lain. Model regresi yang baik adalah yang tidak heteroskedastisitas. Untuk mendeteksi ada atau tidaknya heteroskedastisitas dapat dilakukan dengan melihat ada tidaknya pola tertentu pada grafik scatter plot berikut ini : 


\section{Gambar 3}

\section{Uji Hetetokedastisitas}

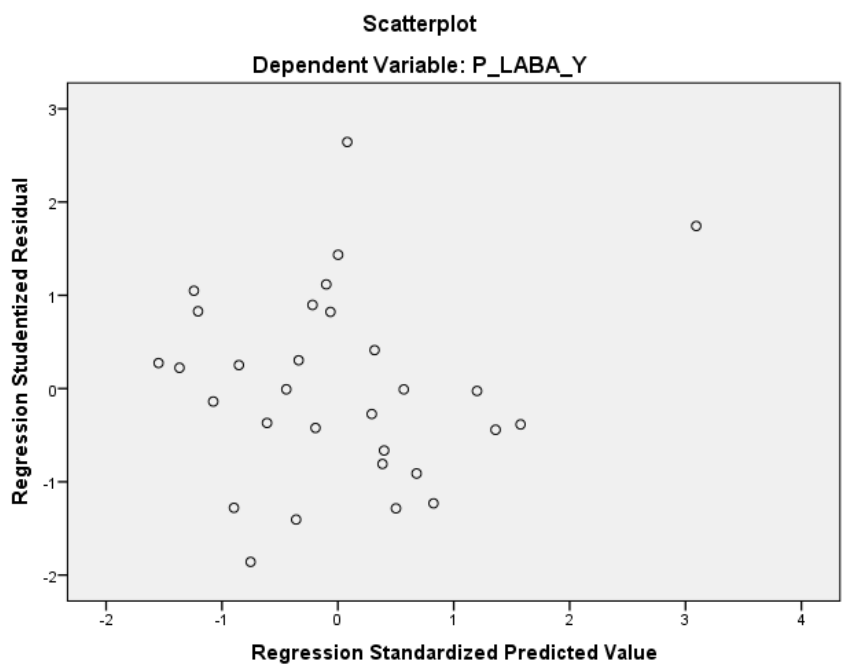

Sumber: Data diolah, 2020.

Hasil Scatterplot pada gambar4.3antara SRESID dan ZPRED terlihat bahwa titik-titik dari data menyebar secara acak serta tersebar dengan baik diatas maupun dibawah angka 0 pada sumbu $Y$ dan tidak membentuk pola tertentu, maka disimpulkan bahwa tidak terjadi Heteroskedastisitas.

\section{Uji Autokorelasi}

Uji autokorelasi bertujuan untuk menguji apakah model regresi linear ada korelasi antara kesalahan pengganggu pada tahun periode $t$ dengan kesalahan pengganggu pada periode $t-1$ (sebelumnya). Terbebasnya suatu model dari autokorelasi dapat dilihat dari angka Dubin Watson pada tabel 4.6 di bawah ini:

Tabel 5

Hasil Uji Autokorelasi

\begin{tabular}{|c|c|c|c|c|c|}
\hline Model & $\mathbf{R}$ & R Square & $\begin{array}{c}\text { Adjusted R } \\
\text { Square }\end{array}$ & $\begin{array}{l}\text { Std. Error of } \\
\text { the Estimate }\end{array}$ & $\begin{array}{l}\text { Durbin- } \\
\text { Watson }\end{array}$ \\
\hline 1 &, $563^{a}$ &, 317 & ,207 & 1,44840 & 2,161 \\
\hline
\end{tabular}

Hasil uji autokorelasi pada Tabel 5 diatas dapat dilihat bahwa nilai Durbin Watson adalah 2,161. Dengan signifikansi 5\%, jumlah unit analisis 30(n) dan variabel independen $4(\mathrm{k}=4)$, maka ditabel DW akan didapatkan nilai sebagai berikut :

\section{Tabel 6}

Durbin-Watson Test Bound

\begin{tabular}{ccc}
\hline & $\mathrm{K}=4$ & \\
$\mathrm{~N}$ & $\mathrm{dL}$ & $\mathrm{dU}$ \\
\hline 10 & 0,376 & 2,414 \\
20 & 0,894 & 0,1828 \\
30 & $\mathbf{1 , 1 4 3}$ & $\mathbf{1 , 7 3 9}$ \\
\hline
\end{tabular}

Sumber: Junaidi (http://junaidichaniago.wordpress.com)

Berdasarkan tabel 6 didapat nilai $\mathrm{dL}=1.143 \mathrm{dan} \mathrm{dU}=1.739$. Nilai DW adalah 2.161 dan berada diantara du dan 4-du. Artinya 2.161 lebih dari dL (1.143) dan kurang dari 4-du (2.261), dengan demikian menujukan bahwa model regresi tersebut sudah bebas dari masalah autikorelasi. 


\section{Uji Multikolinearitas}

Uji multikolinearitas bertujuan untuk menguji apakah model regresi ditemukan adanya korelasi antar variabel bebas (independen). Deteksi multikolinieritas padasuatu mode dapat dilihat dimana nilai Variance Inflation Faktor (VIF) tidak lebih dari 10 dan nilai Tolerance tidak kurang dari 0,1. Maka model tersebut dapat dikatakan terbebas dari multikoliniearitas. Berikut ini adalah hasil Uji Multikoloniearitas :

\section{Tabel 7}

Hasil Uji Multikolinearitas

\begin{tabular}{|c|c|c|c|}
\hline \multirow[b]{2}{*}{ Mod } & & \multicolumn{2}{|c|}{ Collinearity Statistics } \\
\hline & & Tolerance & VIF \\
\hline \multirow[t]{5}{*}{1} & (Constant) & & \\
\hline & CR_X1 & ,551 & 1,816 \\
\hline & DAR_X2 & ,704 & 1,420 \\
\hline & TATO_X3 & ,397 & 2,519 \\
\hline & NPM_X4 & ,368 & 2,714 \\
\hline
\end{tabular}

Hasil uji multikolinearitas yang terdapat pada Tabel 7 menunjukkan model regresi yang dipakai untuk variabel-variabel independen penelitian tidak terdapat masalah multikolinearitas. Model tersebut terbebas dari masalah multikolinearitas karena semua variabel menunjukkan nilai Tolerance tidak kurang dari 0,1 dan mempunyai nilai VIF yang tidak lebih dari 10.

\section{Analisis Regresi Berganda}

\section{Persamaan Regresi Linier Berganda}

Setelah melakukan uji asumsi klasik, langkah berikutnya melakukan regresi linier berganda. Dengan melihat tabel 8 dibawah ini :

\section{Tabel 8}

\section{Regresi Linier Berganda}

\begin{tabular}{|c|c|c|c|c|c|c|}
\hline \multirow{2}{*}{\multicolumn{2}{|c|}{ Model }} & \multicolumn{2}{|c|}{ Unstandardized Coefficients } & \multirow{2}{*}{$\frac{\text { Standardized Coefficients }}{\text { Beta }}$} & \multirow[b]{2}{*}{$\mathrm{t}$} & \multirow{2}{*}{ Sig. } \\
\hline & & $\mathrm{B}$ & Std. Error & & & \\
\hline 1 & (Constant) & 17,559 & 4,837 & & 3,631 & ,001 \\
\hline & CR_X1 & $-4,691$ & 1,415 &,- 695 & $-3,315$ & ,003 \\
\hline & DAR_X2 & $-24,323$ & 8,064 &,- 559 & $-3,016$ & ,006 \\
\hline & TATO_X3 & 1,164 & 3,830 & ,075 & ,304 & ,764 \\
\hline & NPM_X4 & $-3,911$ & 26,998 &,- 037 &,- 145 & ,886 \\
\hline
\end{tabular}

a. Dependent Variable: LABA_Y

Sumber: Data diolah, 2020.

Dari tabel diatas dapat diperoleh persamaan atau model regresi sebagai berikut :

$$
\begin{aligned}
& Y=\beta 0+\beta 1 \mathrm{xt} 1+\beta 2 \mathrm{xt} 2+\beta 3 \mathrm{xt} 3+\beta 4 \mathrm{xt} 4+\mathrm{e} \\
& \mathrm{Y}=17,559-4,691 \mathrm{X}_{1}-24,323 \mathrm{X}_{2}+1,164 \mathrm{X}_{3}-3,911 \mathrm{X}_{4}+\mathrm{e}
\end{aligned}
$$

a. Koefisien Konstanta $(\beta 0)$ sebesar 17,559

Menyatakan bahwa jika $\mathrm{X}_{1}, \mathrm{X}_{2}, \mathrm{X}_{3}, \mathrm{X}_{4}$ adalah 0 , artinya jika current ratio, debt to asset ratio, total asset tornover dan net profit margin masing- masing bernilai 0, maka Perubahan laba bernilai sebesar 17,559 .

b. Koefisien regresi current ratio $\left(\mathrm{X}_{1}\right)$ sebesar $-4,691$

Artinya bahwa setiap penambahan $1 \%$ variable current ratio, maka akan menurunkan nilai perubahan laba sebesar -4,691 dengan asumsi variable lain bernilai tetap. 
c. Koefisien regresi debt to asset ratio $\left(\mathrm{X}_{2}\right)$ sebesar $-24,323$

Artinya bahwa setiap penambahan $1 \%$ variable debt to asset ratio, maka akan menurunkan nilai perubahan laba sebesar -24,323 dengan asumsi variable lain bernilai tetap.

d. Koefisien regresi total asset turnover $\left(\mathrm{X}_{3}\right)$ sebesar 1,164

Artinya bahwa setiap penambahan $1 \%$ variable total asset tornover, maka akanmenambahkan nilai perubahan laba sebesar 1,164 dengan asumsi variable lain bernilai tetap.

e. Koefisien regresi net profit margin $\left(\mathrm{X}_{4}\right)$ sebesar $-3,911$

Artinya bahwa setiap penambahan $1 \%$ variable net profit margin, maka akan menurunkan nilai perubahan laba sebesar -3,911 dengan asumsi variable lain bernilai tetap.

\section{Uji KoefisienDeterminasi (R2)}

Koefisien determinasi (R2) pada intinya mengukur seberapa jauh kemampuan model dalam menerangkan variabel dependen. Perubahaan Labadapat dijelaskan oleh Rasio Keuangan dapatdilihat pada Tabel 9 di bawah ini:

Tabel 9

Hasil Uji KoefisienDeterminasi (R2)

\begin{tabular}{rrrrr}
\hline Model & R & R Square & \multicolumn{1}{c}{$\begin{array}{c}\text { Adjusted R } \\
\text { Square }\end{array}$} & $\begin{array}{r}\text { Std. Error of } \\
\text { the Estimate }\end{array}$ \\
\hline 1 &, $629^{a}$ &, 396 &, 299 & 4,06929 \\
\hline
\end{tabular}

a. Predictors: (Constant), NPM_X4, DAR_X2, CR_X1, TATO_X3

b. Dependent Variable: LABA_Y

Sumber:Output data sekunder yang diolah SPSS 22.0, 2020

Hasil analisis regresi berganda dapat diketahui koefisien determinasi (Adjusted R Square) adalah sebesar 0.299. Berarti variabel bebas dalam penelitian ini mampu menjelaskan varians Perubahaan Labasebesar 29.9\%. Koefisien ini menunjukan bahwa besarnya variable terikat (perubahan laba) dipengaruhi oleh variable bebas (Current ratio, Debt to Asset Ratio, Total Asset Turnover, Net Profit Margin) sebesar 29.9 \% dan sisanya $70.1 \%$ dipengaruhi oleh Variabel lain.

\section{Uji Signifikansi Parsial(Uji-t)}

Uji parsial digunakan untuk mengetahui pengaruh masing-masing variabel independen terhadap variabel dependen. Hasil dari uji parsial data dilihat pada tabel 10 berikut ini :

Tabel 10

Hasil Uji Signifikansi Parsial (Uji-t)

\begin{tabular}{|c|c|c|c|c|c|c|}
\hline & \multirow{3}{*}{ Model } & \multicolumn{5}{|c|}{ Standardized } \\
\hline & & \multicolumn{2}{|c|}{ Unstandardized Coefficients } & \multirow{2}{*}{$\frac{\text { Coefficients }}{\text { Beta }}$} & \multirow[t]{2}{*}{$\mathbf{t}$} & \multirow[t]{2}{*}{ Sig. } \\
\hline & & B & Std. Error & & & \\
\hline \multirow[t]{5}{*}{1} & (Constant) & 17,559 & 4,837 & & 3,631 & ,001 \\
\hline & CR_X1 & $-4,691$ & 1,415 &,- 695 & $-3,315$ & 003 \\
\hline & DAR_X2 & $-24,323$ & 8,064 &,- 559 & $-3,016$ & ,006 \\
\hline & TATŌ_X3 & 1,164 & 3,830 & 075 & ,304 & ,764 \\
\hline & NPM_X4 & $-3,911$ & 26,998 &,- 037 &,- 145 & 886 \\
\hline
\end{tabular}

a. Dependent Variable: LABA_Y

Sumber:Output data sekunder yang diolah SPSS 22.0, 2020

Berdasarkan hasil uji regresi statistik-t pada tabel 10, terlihat bahwa variabel CR dan DAR menunjukkan hubungan yang signifikan terhadap variabel dependennya (Perubahaan Laba) dengan taraf signifikans $\mathrm{i}<5 \%$. Hal ini dapat dilihat dari nilai probabilitas signifikan untuk CRdan DAR masing-masing sebesar 0.003 dan 0.006(sig. <0,05). Sedangkan untuk Variabel TATO, dan NPM 
Menunjukan hubungan yang tidak signifikan terhadap variable dependennya (Perubahaan laba) dengan taraf signifikansi $>5 \%$. Halinidapatdilihat dari nilaiprobabilitas signifikan untuk TATO, NPM yang masing-masing sebesar 0.764 dan 0.886 (sig. <0,05).

\section{Pengujian Hipotesis}

1. Uji Hipotesis 1

Hipotesis 1 menyatakan bahwa Current Ratio berpengaruh signifikan negative terhadap Perubahaan Laba. Pada hasil output SPSS menunjukkan nilai signifikansi sebesar 0.003 yang lebih kecil dari 0,05(sig<0,05) dan nilai koefisien Current ratio sebesar -4,691yang artinya arah hubungan Current ratio (CR) terhadap Perubahaan Labaadalah negatif. Hal tersebut menunjukkan bahwa Current ratio berpengaruh secara signifikan negative terhadapPerubahaan Laba, sehinggaH1 ditolak.

2. Uji Hipotesis 2

Hipotesis 2 menyatakan bahwa Debt to Asset Ratio berpengaruh secara signifikan negatif terhadap Perubahaan Laba. Pada hasil output SPSS menunjukkan nilai signifikansi sebesar 0,006 yang lebih besar dari 0,05(sig<0,05) dan nilai koefisien Debt to Asset Ratio sebesar-24,323 yang artinya arah hubungan Debt to Asset Ratio (DAR) terhadap Perubahaan Laba adalah negatif. Hal tersebut menunjukkan bahwa Debt to Asset Ratio berpengaruh secara signifikan negative terhadap Perubahaan Laba, sehingga H2 diterima.

3. Uji Hipotesis3

Hipotesis 3 menyatakan bahwa Total Asset Turnove rtidak berpengaruh signifikan positif terhadap Perubahaan Laba. Pada hasil output SPSS menunjukkan nilai signifikansi sebesar 0,764 yang lebih besar dari 0,05(sig<0,05) dan nilai koefisien Total Asset Turnover sebesar 1,164 yang artinya arah hubungan Total Asset Turnover terhadap Perubahaan Laba adalah positif. Hal tersebut menunjukkan bahwa Total Asset Turnover tidak berpengaruh secara positif signifikan terhadapPerubahaan Laba, sehingga H3ditolak.

4. Uji Hipotesis 4

Hipotesis 4 menyatakan bahwa Net profit Margin tidak berpengaruh secara signifikan negatif terhadap Perubahaan Laba. Pada hasil output SPSS menunjukkan nilai signifikans isebesar 0,886 yang lebih kecil dari 0,05(sig<0,05) dan nilai koefisien current ratio sebesar -3.992 yang artinya arah hubungan Net Profit Margin terhadap Perubahaan Laba adalah negatif. Hal tersebut menunjukkan bahwa Net Profit Margin tidak berpengaruh secara signifikan negative terhadap Perubahaan Laba, sehinggaH4 ditolak.

\section{KESIMPULAN DAN SARAN}

Berdasarkan hasil pengujian dan pembahasan mengenai pengaruh Variabel Current Ratio, Debt to Total Asset Ratio, Total Asset Turnover, Net Profit Margin terhadap Perubahan Laba maka dapat ditarik kesimpulan dari penelitian ini adalah sebagai berikut :

1. Dengan nilai signifikan sebesar $0.003<0.05$ menunjukkan bahwa Current Ratio berpengaruh signifikan negative terhadap perubahan laba pada perusahaan manufaktur yang terdaftar di Bursa Efek Indonesia periode 2015-2019.

2. Dengan nilai signifikan sebesar $0.0006>0.05$ menunjukan bahwa Debt to Asset Ratio berpengaruh signifikan negative terhadap perubahan laba pada perusahaan manufaktur yang terdaftar di Bursa Efek Indonesia periode 2015-2019.

3. Berdasarkan hasil penelitian yang menunjukkan nilai signifikan sebesar $0.764>0.05$ dapat dijelaskan bahwa Total Asset TurnOver berpengaruh signifikan positif terhadap perubahan laba pada perusahaan manufaktur yang terdaftar di Bursa Efek Indonesia periode 2015-2019.

4. Net Profit Margin tidak berpengaruh secara signifikan negative terhadap perubahan laba pada perusahaan manufaktur yang terdaftar di Bursa Efek Indonesia periode 2015-2019 dengan tingkat signifikan $0.0886<0.05$. 


\section{Saran}

Berdasarkan hasil penelitian yang telah di kemukakan maka dapat diberikan beberapa saran sebagai berikut:

1. Penelitian selanjutnya sebaiknya memperpanjang periode pengamatan dan objek penelitian tidak hanya berfokus pada perusahaan manufaktur.

2. Menambahkan faktor-faktor lain sebagai variabel bebas dalam mempengaruhi perubahan laba seperti Gross Profit Margin, Return On Assets.

\section{DAFTAR PUSTAKA}

Abidin, Z. (2013). Pengaruh Rasio Keuangan Terhadap Perubahan Laba Pada Perusahaan Yang Go Public Di Bursa Efek Indonesia. Sekolah Tinggi Imu Ekonomi Indonesia Surabaya, Volume 02, Nomor 05.

Achmadi, Abu, \& Cholid Narbuko. (2005). Metode Penilitian. Jakarta: Bumi Aksara.

Agus, Wibowo, \& Pujiati. (2011). Analisis Rasio Keuagan Dalam Memprediksi Perubahan Laba Pada Perusahaan Real Estate dan Property di Bursa Efek Indonesia. STIE Perbanas Surabaya Volume 1, Nomor 2, Juli .

Agustina, \& Silvia. (2012). Pengaruh Rasio Keuangan Terhadap Perubahan Laba Pada Perusahaan Manufaktur Yang Terdaftar Di Bursa Efek Indonesia. STIE Mikrosil, Medan. Volume 2, Nomor 02, Oktober.

Arifin. (2007). Membaca Saham. Yogyakarta: Penerbit Andi.

Dermawan Sjahrial., M. (2013). Analisis Laporan Keuangan. Jakarta: Mitra Wacana Media.

Fatimah, S. (2014). Analisis Pengaruh Rasio Keuangan Terhadap Perubahan Laba Pada Perusahaan Manufaktur Sektor Aneka Industri yang Terdaftar di Bursa Efek Indonesia. Universitas Maritim Raja Ali Haji.

Ghozali, I. (2006). Aplikasi Analisis Multivariate Dengan Program SPSS, Cetakan IV. Semarang: Badan Penerbit Universitas Diponegoro.

Hermanda, R. (2015). Pengaruh Rasio Keuangan Terhadap Perubahan Laba. Sekolah Tinggi Imu Ekonomi Indonesia Surabaya, Volume 4, Nomor 01.

Imam, G. (2006). Aplikasi Analisis Multivariate. Semarang: Badan Penerbit niversitas Diponegoro.

Imam, G. (2011). Aplikasi Analisis Multivariate Dengan Program SPSS. Semarang: Badan Penerbit Universitas Diponegoro.

Indonesia, I. A. (2012). Standar Akuntansi Keuangan (PS AK). Jakarta: Salemba Empat.

Irawati. (2005). Analisis Laporan Keuangan. Jakarta: Salemba Empat.

Kasmir. (2008). Analisis Laporan Keuangan. Jakarta: Raja Grafindo Persada.

Kasmir. (2014). Bank dan Lembaga Kenangan Lainnya Edisi Revisi. Jakarta: PT. Raja Grapindo Persada.

Luluk Muhimatul Ifada, \& Tiara Puspitasari. (2016). Analisis Pengaruh Rasio Keuangan Terhadap Perubahan Laba. Fakultas Ekonomi, Unversitas Islam Sultan Agung.

Martono, \& Harjito. (2008). Manajemen Keuangan. Yogyakarta: Ekonisia.

Muslich. (2010). Metode Pengambilan Keputusan Kuantitatif. Jakarta: PT. Bumi Aksara.

Nurmalasari, T. (2012). Analisis Pengaruh Rasio Keuangan Terhadap Laba. Fakultas Ekonomi Universitas Gunadarma.

Poernomo, M. F. (2016). Pengaruh Current Ratio Dan Debt To Equity Ratio Terhadap Profitabilitas Pada Perusahaan Manufaktur Yang Terdaftar Di Bursa Efek Indonesia. Tugas Akhir Program Studi Akuntansi Pelita Bangsa.

Sugiyono. (2007). Metodologi Penelitian Bisnis. Jakarta: Penerbit Erlangga.

Suparno. (2008). Statistik Teori dan Aplikasi. Jakarta: Erlangga.

Syafri, H. S. (2009). Teori Akuntansi. Jakarta: Rajawali Pers. 